\title{
Differential diagnosis of tubal hydatid cyst in the pelvic masses
}

\section{Pelvik kitlelerin ayırıcı tanısında tubal hidatik kist}

\author{
Adnan BUDAK ${ }^{1}$, Aykut ÖZCAN² ${ }^{2}$ Tuğba KARADENIZ ${ }^{3}$, Ramazan GÜVEN ${ }^{4}$, Muzaffer SANCI ${ }^{2}$ \\ ${ }^{1}$ Kadın Hastalıklarl ve Doğum Bölümü, Bitlis Devlet Hastanesi, Bitlis

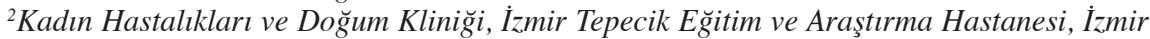 \\ ${ }^{3}$ Tıbbi Patoloji Kliniği, İzmir Tepecik Ĕ̆itim ve Araştırma Hastanesi, İzmir \\ ${ }^{4}$ Acil Tıp Bölümü, Bitlis Devlet Hastanesi, Bitlis
}

\begin{abstract}
Cystic echinococcosis is still an important problem in Turkey. It is most commonly localized in liver and lungs while it may also be rarely observed in the pelvic region. Since it is less common in the pelvic region, it is confused with pelvic hydatid cyst, ovarian cyst and tubaovarian abscess in young ages while it may also be confused with ovarian malignancies in advanced ages. In this case report, we present a female patient G3P3 aged 60 who was found to have hydatid cyst in the lateral site of the uterus on the right tube and the surgical method applied. Pelvic hydatid cyst should be considered as a differential diagnosis in case of cysts detected in the pelvis region. We should consider laparoscopic surgery as one of the first-line choices for treatment.
\end{abstract}

Keywords: hydatid cyst, laparoscopic surgery, pelvic mass

$\ddot{\mathbf{O Z Z}}$

Kistik ekinokokkozis ülkemizin hala önemli bir sorundur. Karaciğer ve akciğer en sık lokalizasyonu olmakla birlikte, daha nadir olarak da pelvik bölgede görülebilmektedir. Pelvik bölgede nadir görüldüğ̈̈̈nden dolayı pelvik hidatik kist, genç yaşlarda over kisti ve tubaovarian abse ile karışırken ileri yaşlarda görüldü̈̆̈̈̈nde ise over maligniteleri ile karışabilmektedir. Biz bu olgu sunumu ile 60 yaşında G3P3 kadın bir hastanın sağ tuba uterina üzerinde uterusun lateralinde saptanan kist hidatik lezyonunu ve sonrasında uygulanan cerrahi yöntemi inceledik. Pelvik bölgede saptanan kitlelerde pelvik kist hidatik ayırıcı tanılardan biri olarak düşünülmelidir. Tedavide ise laporoskopik cerrahiyi ilk seçeneklerden biri olarak düşünmeliyiz.

Alındığı tarih: 06.03.2017

Kabul tarihi: 29.05 .2017

Yazışma adresi: Uzm. Dr. Adnan Budak, Bitlis Devlet Hastanesi, Bitlis / Türkiye

Anahtar kelimeler: hidatik kist, laparoskopik cerrahi, pelvik kitle

e-mail: budakadnan@hotmail.com

\section{INTRODUCTION}

Echinococcal disease is caused by infection with the metacestode stage of the tapeworm Echinococcus, which belongs to the family Taeniidae. Four species of Echinococcus produce infection in humans: E. granulosus and E. multilocularis are the most common culprits which cause cystic echinococcosis (CE) and alveolar echinococcosis (AE), respectively. The two other species E. vogeli and E. oligarthrus cause polycystic echinococcosis, although have been only rarely associated with human infections ${ }^{(1,2)}$.
Cystic echinococcosis still continues to be a very important health problem for underdeveloped countries ${ }^{(3)}$. Although the liver and lung are the most commonly affected organs, the disease may appear rarely in other tissues as a primary disease ${ }^{(2,3)}$.

\section{CASE REPORT}

A 60-year-old female patient was admitted to our outpatient clinic with tenesmus and lower abdominal pain for three months. His medical history was nonremarkable. Physical examination showed abdominal 
tenderness. Abdominal X-ray showed non-specific findings. Abdominal ultrasonography (USG) showed a $5 \times 6 \times 5.5 \mathrm{~cm}$ in-size cystic lesion of the right adnexa. A multi-septated cystic lesion of the uterus was detected by computed tomography (CT).

On admission, her blood pressure was 130/80 $\mathrm{mmHg}$, body temperature was $36.8^{\circ} \mathrm{C}$, and the pulse was 78 per min. Mild tenderness was determined in the abdominal area. Laboratory test results revealed that all routine blood tests and tumor markers were within the normal range. Anti-echinococcal antibodies (IHA) were negative. Hysterectomy and bilateral salpingo-oophorectomy were performed by the gynecological surgery department. The whole specimen was sent for pathological assessment (Figure 1). The histopathological finding of Hematoxylin and Eosin (H\&E) section revealed a double-layered membrane with an outer laminated hyaline membrane and inner

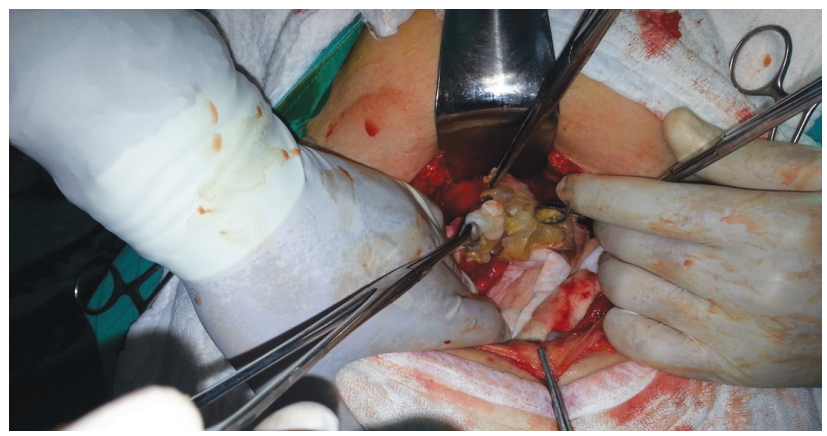

Figure 1. A laparotomy image. A $5 \times 6 \mathrm{~cm}$ cystic structure adjacent to the right lateral of the uterus fundus, located on the right uterine tube and not connected with the right ovary. The cyst had adhesions with the surrounding tissues, and retracted the bladder peritoneum. During the isolation of the adhesions, the cyst was ruptured. A clear liquid and a daughter vesicle were observed inside the cyst.

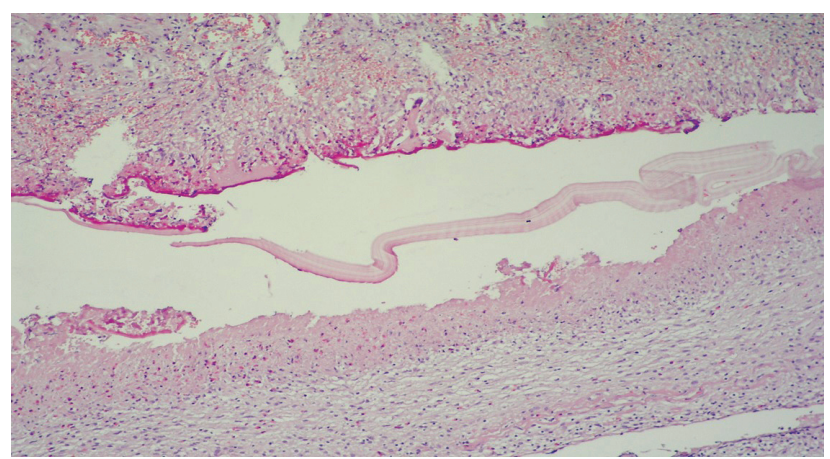

Figure 2. Histopathological examination. Cuticular membrane of the $\mathrm{HC}$ and scolex in the tissue examined. granular germinal layer (Figures 2, 3). Albendazole was initiated as the primary anti-parasitic agent for postoperative treatment of E. granulosus. The patient was scheduled for follow-up every three to six months and annually thereafter.

\section{DISCUSSION}

In addition to being an occupational disease with worldwide distribution, cystic echinococcosis or hydatid disease is one of the most significant zoonotic diseases ${ }^{(4)}$. As parasitic disease, cystic echinococcosis develops cysts which develop from Echinococcus-type cestodes both in humans and animals, and it continues to be an important health problem in Turkey ${ }^{(5)}$.

Pelvic hydatid disease is rare with a reported incidence of 0.2 to $0.9 \%$ in certain regions ${ }^{(6)}$. Several reports present single cases of pelvic hydatid cyst ${ }^{(7)}$, while only a few present a series of cases ${ }^{(4,6,7)}$. The recently reported 11-case series is one of the largest ever presented in Tunisia ${ }^{(8)}$. It reports three new cases of primary pelvic hydatid cyst, which is an extremely rare condition. Also, it includes a case of hydatid cyst of the fallopian tube, one of the rarest pelvic locations.

Imaging tools are of utmost importance, due to the lack of specific clinical signs of the disease. The USG is the primary diagnostic tool thanks to its low cost and high sensitivity. Type II and III hydatid cyst are pathognomonic, while the other cyst types often resemble other lesions ${ }^{(8,9)}$.

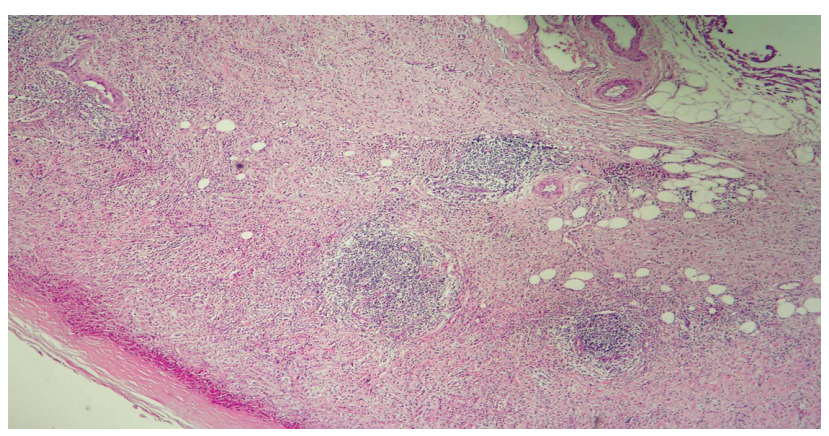

Figure 3. Connection of uterine tube with the hydatid cyst. Chronic inflammation and fibrosis in the uterus, right uterine tube, and peritoneal area around the cyst. 
Type I cysts appear purely cystic and unilocular and, when located on the ovary, they are often misdiagnosed as other types of ovarian cysts or as hydrosalpinx ${ }^{(9)}$. Type II cysts appear as fluid-filled with a floating membrane (the "water lily" sign) corresponding to a detached germinative membrane ${ }^{(9)}$. Type III cysts are filled with daughter vesicles and have a characteristic honeycomb appearance ${ }^{(9)}$. Type IV cysts appear as heterogeneous masses and are often misdiagnosed as pelvic malignancies. In some cases, type IV cysts may present a "whorl" image, which is indicative of collapsed hydatid membranes ${ }^{(9)}$. Types V cysts have calcified walls and are often misdiagnosed as fibromas ${ }^{(9,10)}$. In our case, USG led to the correct diagnosis. In general, compared to USG, computed tomography (CT) allows for a better evaluation of cystic masses, since the clearer evidence of their extension enables to anticipate surgical complications ${ }^{(6)}$.

On the other hand, the mechanism of pelvic involvement has not been clearly explained. Although pelvic hydatid disease is almost always considered to be secondary and, due to the rupture into the peritoneum of a hepatic or splenic hydatid cyst, ${ }^{(1)}$ some cases of primary pelvic echinococcosis have been described $^{(7,8,10,11)}$. Our case was also of primary pelvic hydatid disease. The genital tract is the most frequently affected region of the pelvic locations, accounting for up to $80 \%$ all pelvic cases in the genital tract ${ }^{(12)}$. However, the ovary seems to be the most affected genital organ ${ }^{(12)}$. Moreover, the fallopian tubes are rarely affected ${ }^{(7,10)}$, whereas retroperitoneal and retrovesical locations account for $0.5 \%$ to $2 \%$ of all hydatid locations ${ }^{(13)}$. In addition, pelvic hydatid cysts may develop in the peritoneal cavity independently of the surrounding organs.

The mainstay of hydatid disease management is surgery. Laparotomy through a midline incision is classically performed. To avoid dissemination, the surgical site should be packed with sponges soaked in a scolicidal solution and the cyst cavity should be irrigated with scolicidal agents ${ }^{(14)}$. To prevent recurrence, the first step is to fully explore the abdominal cavity and not to misdiagnose the cysts. Then, hydatid cysts are managed surgically through partial or total cystectomy ${ }^{(15)}$. Whenever possible, total cystectomy is the most optimal option, as it prevents perioperative rupture of the cyst. In our case, complete cystectomy was performed. Rahman et al. ${ }^{(12)}$ recommended oophorectomy in young women with ovarian hydatid cyst in the presence of a healthy contralateral ovary and bilateral oophorectomy in postmenopausal women. In contrast, other authors consider that the most optimal option for women of reproductive age is complete cystectomy ${ }^{(16,17)}$.

Several articles have been published on successful laparoscopic procedures for hepatic hydatid cysts, although only a few are about the laparoscopic removal of pelvic hydatid cysts ${ }^{(18)}$. One of the main critics of the laparoscopic approach is the risk of spillage of the hydatid cyst fluid, enhanced by the abdominal pressure induced by the pneumoperitoneum ${ }^{(19)}$. However, consistent with previous reports, we believe that spillage can be prevented, if precautionary measures are taken, such as using gauzes soaked in a scolicidal solution to isolate the surgical site and aspirating meticulously to avoid spillage. Previous reports, mostly focusing on hepatic hydatid cysts, conclude that the laparoscopic approach is safe and effective, and offers all the advantages of minimally invasive surgery ${ }^{(20)}$.

Postoperative follow-up is based on clinical examination, abdominal USG exploration, and serologic tests. Long-term follow-up over many years is recommended ${ }^{(21)}$. The recurrence rate ranges from 8 to $20 \%{ }^{(22)}$. In our case, no recurrence was observed at 20 months following surgery.

In conclusion, hydatid cysts should be considered in the differential diagnosis of abdominopelvic masses, particularly in areas where hydatid disease is endemic. The USG is the primary imaging diagnostic tool. A chest radiograph and an abdominal USG scan should be always performed to ensure that the hydatid cyst is not located in the pelvic region. Surgery is the treatment of choice, and laparoscopy can be safely done, when precautionary measures are taken to 
avoid spillage. The gastrointestinal surgeon should be present to treat frequently associated hepatic and/ or splenic hydatid cysts. Long-term follow-up is essential to diagnose and manage the disease in a timely manner and to avoid recurrence.

\section{REFERENCES}

1. Ben Rejeb C, Dhifallah S, Bibi M, Nouira M, Memmi A, Chaieb A et al. Bilateral hydatid cyst of the fallopi antubes: a case report. J Gynecol Obstet Biol Reprod. 2001;30:70-3.

2. Bouree P. Hydatidosis: dynamics of transmission. World $\mathbf{J}$ Surg. 2001;25:4-9. https://doi.org/10.1007/s002680020001

3. Ito A, Urbani C, Jiamin Q, Vuitton DA, Dongchuan Q, Health DD et al. Control of echinococcosis and cysticercosis: a public health challenge to international cooperation in China. Acta Trop. 2003;86:3-17. https://doi.org/10.1016/S0001-706X(02)00269-3

4. Ammann RW and Eckert J. Cestodes. Echinococcus. Gastroenteral Clin North Am. 1996;25:655-89. https://doi.org/10.1016/S0889-8553(05)70268-5

5. Ozekinci S, Bakir S and Mizrak B. Evaluation of Cystic Echinococcosis Cases Given a Histopathologic Diagnosis from 2002 to 2007 in Diyarbakir. Turkiye Parazitol Derg. 2009;33:232-35.

6. Terek MC, Ayhan C, Ulukuş M, Zekioğlu O, Ozkinay E and Erhan Y. Primary pelvic hydatidcyst. Arch Gynecol Obstet. 2000;264(2):93-6. https://doi.org/10.1007/s004040000068

7. Engin G, Acunas B, Rozanes I and Acunas G. Hydatid disease with unusual localization. Eur Radiol. 2000;10:1904-12. https://doi.org/10.1007/s003300000468

8. Chelli D, MethniA, Gatri C, Boudaya F, Affes $M$ and Chennoufi MB. Pelvic hydatid (echinococcal) disease. Int J Gynaecol Obstet. 2010;109(1):45-8. https://doi.org/10.1016/j.ijgo.2009.10.021

9. Gharbi HA, Hassine W, Brauner MW and Dupuch K. Ultrasoun dexamination of the hydatic liver. Radiology. 1981;139(2):459-63. https://doi.org/10.1148/radiology.139.2.7220891

10. Mushtaque M, Mir MF, Malik AA, Arif SH, Khanday SA and Dar RA.A typical localizations of hydatid disease: Experience from a single institute. Niger J Surg. 2012;18:2-7.
11. Atmatzidis K, Papaziogas B, Mirelis C, Pavlidis T and Papaziogas T. Splenectomy versus spleen-preserving surgery for splenic echinococcosis. Dig Surg. 2003;20:527-31. https://doi.org/10.1159/000073689

12. Rahman MS, Rahman J and Lysikiewicz A. Obstetric and gynecological presentations of hydatid disease. Br J Obstet Gynaecol. 1982;89:665-70. https://doi.org/10.1111/j.1471-0528.1982.tb04723.x

13. Kandhrah E, Semercioz A, Metin A, Eroglu M and Uysal B. Non-functioning kidney resulted from primary hydatid cyst of the psoasmuscle. MMJ. 2006;19:145-6.

14. Prabhudessai SC, Patankar RV and Bradoo A. Laparoscopic treatment of renal hydatid cyst. J Minim Access Surg. 2009;5:20-1. https://doi.org/10.4103/0972-9941.51317

15. Smego RA and Sebanego P. Treatment options for hepatic cystic echinococcosis. Int J Infect Dis. 2005;9:69-76 https://doi.org/10.1016/j.ijid.2004.08.001

16. Citgez B, Battal M, Cipe G, Karatepe O and Muslumanoglu M. Feasibility and safety of laparoscopic hydatid surgery: a systematic review. Hepato-Gastroenterology 2013;60:784-8.

17. Fatin R. Hydatidcyst: open or laparoscopic approach? A retrospective analysis. Surgery, Laparoscopy, Endoscopy, and Percutaneous Techniques. 2012;22:264-6. https://doi.org/10.1097/SLE.0b013e318251625c

18. Belli L, Del Favero E, Marni A and Romani F. Resection versus pericystectomy in the treatment of hydatidosis of the liver. Am J Surg. 1983; 145:239-42. https://doi.org/10.1016/0002-9610(83)90070-3

19. Palanivelu C, Senthilkumar R, Jani K, Rajan PS, Parthasarthi $\mathrm{R}$ and Rajapandian S. Palanivelu hydatid system for safe and efficacious laparoscopic management of hepatic hydatid disease. Surg Endosc. 2006;20:1909-13. https://doi.org/10.1007/s00464-005-0274-7

20. Georgescu S, Dubei L, Tarcoveanu E, Bradea C, Lazescu D, Crumpei $\mathrm{F}$ et al. Minimally invasive treatment of hepatic hydatid cysts. Rom J Gastro. 2005;9:249-52.

21. Galitza Z, Bazarsky E, Sneier R, Peiser J and El-On J Repeated treatment of cysticechinococcosis in patients with a long-term immunological response after successful surgical cystremoval. Trans R Soc Trop Med Hyg. 2006;100:126-33. https://doi.org/10.1016/j.trstmh.2005.05.014

22. Daradkeh S, El-Muhtaseb H, Farah G, Sroujieh A.S andAbuKhalaf M. Predictors of morbidity and mortality in the surgical management of hydatid cyst of theliver. Langenbecks Arch Surg. 2007;392:35-9. https://doi.org/10.1007/s00423-006-0064-2 